\title{
Tanggung Jawab Direksi dalam Meningkatkan Citra Bank (Suatu Telaah Yuridis Normatif)
}

\author{
Sriayu Indah Puspita ${ }^{1}$ \\ Fakultas Hukum Universitas Batanghari \\ Correspondence email: izzy_euys@yahoo.com
}

\begin{abstract}
Abstrak. Pada zaman ini dunia perbankan mempunyai fungsi yang sangat penting pada sistem roda perekonomian Indonesia. Perbankan merupakan suatu lembaga yang berfungsi untuk menghimpun sekaligus menyalurkan dana masyarakat. Untuk itu agar tetap memperoleh kepercayaan masyarakat terhadap bank, pemerintah terus berusaha untuk memproteksi atau melindungi masyarakat dari oknum-oknum yang tidak bertanggung jawab yang dapat merusak kepercayaan masyarakat terhadap bank tersebut. Persoalan pertanggung-jawaban perdata atas keteledoran atau kecerobohan yang terjadi dalam bank dapat di kaitkan dengan kepengurusan bank tersebut. Untuk meningkatkan fungsi kesadaran bersama terhadap lembaga perbankan, peraturan mengenai rahasia bank yang selama ini sangat tertutup harus segera direvisi ulang. Rahasia bank dimaksud adalah salah satu unsur yang perlu dimiliki oleh setiap bank sebagai lembaga kepercayaan masyarakat. Praktek perbankan yang melanggar dari aturan Undang-Undang di sektor Perbankan sepanjang aturan tersebut dianggap sebagai kelemahan yang dapat merugikan kepentingannya, bahkan pemilik atau pengurus Bank menggunakan celah aturan yang ada sehingga pada akhirnya mengakibatkan bank berada pada kondisi yang tidak sehat. Untuk itu kita perlu mengetahui dan memahami bagaimana bank tersebut dapat meningkatkan citranya serta peranan direksi dalam mengatasi persoalan-persoalan yang dihadapi serta bagaimana cara mengatasi persoalan tersebut. Direksi mempunyai peranan penting dalam kepengurusan bank, direksi juga wajib mengatur bank sesuai kewewenagan dan tanggung jawabnya sebagaimana diatur dalama anggaran dasar dan ketentuan aturan berlaku. Citra bank di bangun melalui program komunikasi dan dipadukan oleh pengalaman nasabah berinteraksi dengan bank.Citra bank dapat juga ditunjukan dengan bank yang besar, produknya, pelayanannya, serta banyaknya nasabah.
\end{abstract}

Kata Kunci: Sistem Perbankan, Citra Bank dan Tanggung Jawab

\begin{abstract}
At this time the banking world has a very important function in the Indonesian economy. Banking is an institution that functions to collect and distribute public funds. For this reason, in order to maintain public trust in the bank, the government continues to try to protect or protect the public from irresponsible persons who can damage public trust in the bank. The issue of civil liability for negligence or carelessness that occurs in a bank can be related to the management of the bank. In order to increase the function of common awareness towards banking institutions, regulations regarding bank secrecy which have been very secretive must be revised immediately. The bank secrecy in question is one of the elements that every bank needs to have as an institution of public trust. Banking practices that violate the laws and regulations in the banking sector as long as these regulations are considered a weakness that can harm their interests, even the owner or management of the bank uses the existing regulatory loopholes so that in the end the bank is in an unhealthy condition. For that we need to know and understand how the bank can improve its image and the role of the board of directors in overcoming the problems faced and how to overcome these problems. The Board of Directors has an important role in the management of the bank, the board of directors is also required to regulate the bank according to its authority and responsibility as stipulated in the articles of association and the provisions of the applicable regulations. The image of the bank is built through communication programs and combined with customer experiences interacting with the bank.
\end{abstract}

Keywords: Banking System, Bank Image and Responsibility

\section{PENDAHULUAN}

Perbankan sering disebut sebagai jantung dari sistem keuangan, karena perbankan menerima simpanan uang dalam bentuk Tabungan, Deposito dan Rekening Giro milik masyarakat, baik milik individu, Badan Usaha Milik Negara (BUMN) maupun perusahaan - perusahaan swasta. Untuk itu guna tetap memperoleh kepercayaan masyarakat terhadap bank, pemerintah harus berusaha melindungi masyarakat dari tindakan lembaga, ataupun oknum yang tidak bertanggung jawab dan merusak sendi kepercayaan masyarakat. Masalah tanggung jawab perdata atas kelalaian atau kesalahan yang terjadi dalam bank dapat di hubungkan dengan kepengurusan bank tersebut. Pengurus Bank bertindakan mewakili badan hukum tersebut berdasakan ketentuan Anggaran Dasar Perusahaan.

Struktural Bank Indonesia dipimpin oleh Direksi yang terdiri atas seorang Gubernur sekurang-kurangnya lima (5) dan sebanyak-banyaknya tujuh (7) orang direktur. Dan sebanyak- sebanyaknya dua (2) orang direktur ditunjuk oleh Presiden sebagai pengganti Gubernur jika Gubernur berhalangan. Antara anggota direktur tidak ada hubungan

${ }^{1}$ Dosen Fakultas Hukum Universitas Batanghari 
keluarga sampai derajat ketiga menurut garis lurus, maupun garis kesamping termasuk menantu dan ipar. Direksi mewakili bank di dalam maupun di luar pengadilan. ${ }^{2}$

Supaya terwujudnya sistem perbankan yang dinamis, aman, terpercaya serta profesional dalam menjalankan fungsi dan wewenang Perbankan, ada sejumlah Prinsip yang harus dijalankan oleh perbankan, diantaranya dapat menerapkan prinsip kehati-hatian (Prudential), keamanan (Safety), keuntungan (Profitability) dan efisiensi sehingga tercapainya sistem Perbankan Nasional kearah yang di cita-citakan.

Bank Indonesia merupakan lembaga pengawas semua jenis bank di Indonesia, yang mempunyai tugas yang sangat penting dalam menjamin serta melindungi masyarakat pengguna bank dari oknum-oknum bank yang tidak bertanggung jawab. Untuk itu Bank Indonesia diminta lebih profesional dalam menjalankan tugas serta wewenang dalam mengawasi pelaksanaan aturan-aturan undang-undang yang wajib di patuhi oleh seluruh bank di Indonesia. Pengawasan yang dilakukan tersebut setidaknya dapat mengurangi kasus-kasus yang dapat menimbulkan kerugian pemakai jasa bank. ${ }^{3}$

Namun demikian, buruknya kondisi perbankan di Indonesia tersebut sesungguhnya tidak semata - mata diakibatkan oleh krisis moneter melainkan juga di sebabkan oleh anggota intern di dalam bank tersebut. Adanya oknum-oknum yang melakukan praktek menyimpang yang tidak sesuai dengan Peraturan Perundang-undangan dapat memperburuk kondisi di bidang perbankan dan hal tersebut menimbulkan kerugian, bahkan Direksi atau pengelola bank yang dengan sengaja melakukan praktek menyimpang tersebut akan berakibat bank dalam kondisi yang tidak sehat. Di samping itu, direksi atau pengelola bank dalam menjalankan tugas dan fungsinya, tidak memperhatikan prinsip kehati - hatian, dapat menyebabkan lemahnya sistem internal sektor perbankan terutama sebagai dampak lemahnya manajemen. Maka dari itu penulis merumuskan masalah terkait dengan jurnal ini adalah Bagaimanakah tanggung jawab Direksi dalam Meningkatkan Citra Bank?

\section{METODE}

Metodelogi yang digunakan dalam penelitian yang yaitu menggunakan tipe penelitian yang bersifat yuridis normative, karena Penulis mengkaitkan masalah yang ada pada penelitian dengan aturan norma-norma yang termuat pada suatu aturan hukum perundangan, yang konsep pendekatan penulisan jurnal ini lebih menitikberatkan mengenai perundangan yang berkaitan dengan masalah tanggung jawab direksi dalam meningkatkan citra bank.

\section{HASIL DAN PEMBAHASAN}

\section{Tanggung Jawab Direksi Dalam Meningkatkan Citra Bank}

Berdasarkan Aturan Bank Indonesia tentang pelaksanaan Good Corporate Governance (GCG) atau Tata Kelola

Perusahaan bagi Bank Umum dengan Nomor 8/4/PBI/2006, adalah sebagai berikut :

1. Prinsip- prinsip Good Corporate Governance wajib dilaksanakan oleh bank dalam menjalankan setiap kegiatan usahanya. Pelaksanan prinsip- prinsip Good Corporate Governance sebagaimana dimaksud yaitu :

a. Tugas dan tanggung jawab yang dilaksanakan Dewan Komisaris dan Direksi

b. Tentang Penyediaan dana dari pihak-pihak terkait

c. Tentang fungsi auditor internal dan auditor eksternal serta fungsi kepatuhan

d. Tentang pelaksanaan dan kelengkapan tugas komite- komite dan satuan kerja yang menjalankan fungsi pengendalian intern bank

e. Tentang manajemen risiko, serta sistem pengendalian intern

f. Tentang transparansi kondisi keuangan dan non keuangan Bank

g. Rencana strategis Bank

2. Pelaksanan Good Corporate Governance yang telah dinilai oleh Bank Indonesia.

3. Anggota dewan Komisaris berjumlah 3 (tiga) atau lebih kurang sama dengan jumlah anggota direksi, dan setidaknya 1 (satu) orang wajib tinggal dan berdomisili di Indonesia

4. Direksi dipimpin oleh Presiden Direktur atau Direktur Utama

5. Presiden Direktur atau Direktur harus berasal dari pihak yang independen terhadap pemegang saham pengendali.

6. Setiap usulan penggantian atau pengangkatan anggota Direksi oleh dewan komisaris kepada Rapat Umum Pemegang Saham, harus memperhatikan rekomendasi Komite Remunerasi dan Nominasi, dengan mayoritas anggotanya harus memiliki pengalaman di bidang operasional sebagai Pejabat Eksekutif bank setidaknya 5 (lima) tahun dan tidak berlaku bagi bank umum yang melaksanakan kegiatan usaha berdasarkan prinsip syariah. Dan juga harus memenuhi persyaratan telah lulus penilaian kemampuan dan kepatuhan sesuai dengan ketentuan Bank Indonesia.

\footnotetext{
${ }^{2}$ Muhammad Djumhana, Hukum Perbankan Di Indonesia, PT.Citra Aditya Bakti : Bandung, 2006, Halaman 89

${ }^{3}$ Widjanarto, Hukum dan Ketentuan Perbankan di Indonesia, Grafiti, Jakarta, 2005, halaman 25
} 
7. Dilarang merangkap jabatan sebagai anggota dewan Komisaris, Direksi atau Pejabat Eksekutif pada Bank atau perusahan lain dan dilarang memiliki saham melebihi 25\%( duapuluh lima perseratus) dari modal disetor pada Bank dan/ atau pada perusahan lain.

8. Mayoritas anggota direksi dilarang saling memiliki hubungan keluarga sampai derajat kedua dengan sesama anggota direksi dan / atau dengan anggota dewan komisaris.

9. Anggota Direksi dilarang memberikan kuasa umum kepada pihak lain yang mengakibatkan pengalihan tugas dan fungsi Direksi.

10.Direksi mempunyai tanggung jawab yang penuh terhadap pelaksanaan pengelolaan kepengurusan bank sesuai dengan aturan perundangan yang berlaku.

11.Setiap kegiatan usaha bank, Direksi wajib menggunakan prinsip- prinsip Good Corporate Governance.

12.Direksi wajib mempertanggungjawabkan segala sesuatu yang berkaitan tugasnya kepada Rapat Umum Pemegang Saham.

13.Jika terjadi penemuan-penemuan, Direksi wajib meng-audit satuan kerja audit intern bank, auditor eksternal, serta hasil pengawasan otoritas lain.

14.Direksi wajib membentuk Satuan kerja audit intern, Satuan kerja manajemen risiko dan komite manajemen risiko serta Satuan kerja kepatuhan.

15.Direksi wajib mengungkapkan kepada pegawai kebijaksanaan bank yang bersifat strategis di bidang kepegawaian.

16.Direksi dilarang menggunakan penasihat perorangan dan/ atau jasa profesional sebagai konsultan kecuali memenuhi persyaratan sebagai berikut;

a. Proyek bersifat khusus

b. Didasari oleh kontrak yang jelas, yang sekurang-kurangnya mencakup lingkup kerja, tanggung jawab dan jangka waktu pekerjaan serta biayanya.

17.Segala keputusan yang diambil oleh Direksi bersifat mengikat berdasarkan pedoman dan tata tertib kerja serta menjadi tanggung jawab seluruh anggota direksi.

18.Anggota Direksi wajib mengungkapkan :

a. Kepemilikan sahamnya, baik pada bank yang bersangkutan maupun pada bank dan perusahaan lain yang berkedudukan di dalam dan diluar negeri

b. Hubungan keuangan dan hal keluarga dengan anggota dewan komisaris, anggota direksi lain dan / atau Pemegang Saham Bank ( pasal 36). ${ }^{4}$

Dari penjelasan pasal- pasal yang telah diuraikan diatas, dapat dilihat dengan jelas tanggung jawab direksi secara umum, yaitu :

a. Pelaksanaan Kepengurusan Bank adalah menjadi tanggung jawab penuh Direksi.

b. Pengelolaan Bank sesuai dalam Anggaran Dasar dan Peraturan Perundang-Undangan yang berlaku, menjadi dengan kewenangan dan tanggung jawabnya Direksi berdasarkan prinsip-prinsip GCG (Good Corporete Governance ) serta dilaporkan kepada pemegang saham melalui Rapat Umum Pemegang Saham.

Sebagai contoh PT. Bank Pembangunan Daerah Jambi merupakan Perusahaan Milik Daerah, yang mana berbentuk Badan Hukum PT. harus tunduk dan patuh pada Undang-undang Nomor 40 Tahun 2007 Tentang Perseroan Terbatas dan Undang-Undang Nomor 10 Tahun 1998 Tentang Perbankan. Tanggung jawab direksi Bank Pembangunan Daerah atau yang sekarang dikenal dengan Bank Jambi adalah sebagai berikut :

a. Direksi Bank Jambi bertanggung jawab menetapkan arah strategi usaha bank,serta memantau dan memastikan bahwa arah strategi tersebut dijalankan demi terciptanya sasaran dan tujuan perseroan, mengelola aktifa dan kewajiban perseroan.

b. Mengelola Bank Jambi agar dapat menghasilkan keuntungan (profitability) dan memastikan kesinambungan usaha (sustainability) sesuai dengan Anggaran Dasar bank dan peraturan perundang-undangan yang berlaku.

c. Direksi mengangkat dan memberhentikan pegawai serta menentukan susunan organisasi dan tata kerja perseroan dengan persetujuan komisaris. ${ }^{5}$

Tanggung jawab diatas diterapkan direksi dalam meningkatkan citra bank yang dipimpinnya, dimana hanya sedikit bank yang namanya muncul sebagai top of mind , untuk mendapatkan tempat di benak konsumen, bank- bank lain harus membangun citra bank . Impersi tentang suatu merek bank dikenal dengan istilah brand image dan meliputi semua hal yang bersifat positif. Citra Bank sering diamati berdasarkan

1. Aspek Kinerja, seperti menyediakan produk bervariasi, menyediakan layanan staf yang ramah dan cepat, jaringan askes yang luas, bunga yang tinggi.

\footnotetext{
${ }^{4}$ http://www.peraturan.bank.indonesia.co.id

${ }^{5} \mathrm{http}: / / \mathrm{www} \cdot$ bankjambi.co.id/?v=vscf\&id=15
} 
2. Aspek Emosional, misalnya bank pemimpin pasar, bank yang dapat dipercaya, pemimpin dalam teknologi dan inovasi, bank yang mengerti kebutuhan nasabah.

3. .Aspek Kepribadian, misalnya bank yang kompeten, bank yang ceria, bank yang jujur, bank dengan pribadi yang modren.

4. Apek Relasi, yaitu bank yang menjadi bagian penting bagi nasabah, bank yang komit bagi nasabah. ${ }^{6}$

Citra Bank di bangun melalui program komunikasi dan dipadukan oleh pengalaman nasabah berinteraksi dengan bank. Aspek citra adalah unsur utama dalam kekuatan atau ekuitas merek, yang menjadi aset bank. Dengan mengetahui persepsi masyarakat terhadap dirinya, bank bisa memperbaiki perilaku dan penapilannya serta membuat strategi komunikasi yang lebih efektif, sehingga ekuitas makin tinggi.

Dari hasil Monitoring Marketing Research Indonesia (MRI) terhadap isu yang dibicarakan berdasarkan suatu survei, yang mana survei ini tidak untuk menggambarkan kondisi nasional, tetapi mencoba menangkap berbagai tren yang terjadi. Adapun nama- nama bank yang muncul secara top of mind relatif sedikit, yaitu belasan saja. Tingkat pengenalan top of mind, yang paling penting dalam pemasaran dikuasai 4 (empat) bank saja yaitu: Bank Swasta Nasional (Bank Central Asia atau BCA) dengan penguasaan 36\%, Bank Mandiri 26\%, Bank Rakyat Indonesia atau BRI 19\%, dan Bank Negara Indonesia atau BNI 12\%

Bank yang top of mind dapat dilihat 2 (dua hal), yaitu bank yang akses bank- bank tertentu yang mudah melalui banyak cabang dan melalui Automatic Teller Mechine (ATM) yang terbesar dan bank yang aman.sudah barang tentu ada yang melihat dari sisi- sisi lain, seperti :

1. Bank terbesar

2. Produknya

3. Pelayanannya

4. Banyaknya nasabah

Keamanan dalam perbankan tentu mendasar, dan ketika hal tersebut banyak dibicarakan konsumen, ini menunjukan adanya kekhawatiran konsumen akan hal itu. Mungkin dibicarakannya Merger, Akuisisi, maupun Konsolidasi sejumlah bank. Secara spesifik, BCA di pandang sebagai bank yang memiliki jangkauan yang sangat luas, terutama melalui produk Anjungan Tunai Mandiri-nya, dan di pandang masyarakat sebagai bank terbesar.

Bank Mandiri tampak kuat melalui dua sisi, yaitu akses dan keamanan. Kekuatan akses Bank Mandiri lebih dilihat melalui cabang yang banyak ketimbang jumlah ATM-nya. Selain itu berbeda degan bank- bank lain, Bank Mandiri relatif paling banyak diasosiasikan dengan pelayanan staf yang baik, sedangkan BNI agak lebih kuat diasosiasikan sebagai bank yang aman.

Eksplorasi citra bank selanjutnya dilakukan dengan 20 atribut yang beragam dalam hal pengenalan, kepercayaan, profesionalisme, dan sebagainya. Bank yang paling dikenal masyarakat yaitu BCA yang menyerap kebanyakan atribut, yakni atribut 17 atribut dari 20 atribut yang digunakan. Sesuatu kekuatan ekuitas yang luar biasa, Kekuatan persepsi bank dengan Anjungan Tunai Mandiri -nya terbanyak, jumlah cabang, komunikasi yang gencar, serta promosi-promosi yang menarik dan bank tersebut bisa digunakan juga di berbagai negara Asia.

Dimana citra suatu bank ditunjukkan juga dengan sehat atau tidaknya suatu bank tersebut. Bank yang dapat di kategorikan kondisi sehat ialah bank yang dapat menjaga kepercayaan masyarakatnya dan juga bank tersebut yang dapat menjalankan fungsi-fungsinya dengan baik, termasuk menjalankan fungsi intermediasi dalam kelancaran lalu lintas pembayaran serta dipergunakan dalam melaksanakan berbagai kebijakan terutama kebijakan moneter oleh pemerintah.

Agar suatu bank dapat menjalankan fungsinya dengan baik, bank harus ditunjang dengan aset yang memadai serta bank tersebut menjaga kualitas asetnya, dengan cara manajemen tersebut harus dilaksanakan berdasarkan azas kehati-hatian, sehingga dapat memperoleh keuntungan yang juga dapat menambah kemakmuran bagi para nasabahnya, serta memelihara likuiditasnya yang dapat melaksanakan kewajibannya setiap waktu.

Bank wajib memelihara tingkat kesehatannya sesuai dengan ketentuan kecukupan modal, kualitas menajemen, likuiditas, rentabilitas, dan solvabilitas, serta aspek-aspek lain yang berkaitan dengan usaha bank dan wajib melakukan kegiatan usaha sesuai dengan prinsip kehati-hatian.

Penilaian tingkat Kesehatan Bank Indonesia sampai saat ini secara garis basar didasarkan pada faktor CAMEL (Capital, Assets Quality, Manajemen, Earning, dan Liquidity) Kelima faktor ini merupakan faktor yang menentukan kondisi suatu bank. Apabila suatu bank mengalami permasalahan pada salah satu faktor saja, maka bank tersebut dinyatakan akan mengalami kesulitan. Sebagai contoh: suatu bank mengalami masalah Likuiditas (meskipun Bank tersebut modalnya cukup, selalu untung, dikelola dengan baik, kualitas aktifa produktifnya baik), apabila Permasalahan tersebut tidak capat diatasi, dapat dipastikan bank tersebut tidak sehat, dengan tidak sehatnya bank tersebut maka menyebabkan citra bank menjadi tidak baik.

${ }^{6}$ http://www .infobanknews.com / artikel /rubrik/artikel -cetak. Php ? aid=... 

yaitu :

Adapun faktor-faktor bank yang dikatakan sehat sehingga menyebabkan bank tersebut memiliki citra yang baik

1. Kecukupan Modal (capital)

Suatu Bank jika dikatakan Sehat apabila bank tersebut tidak memiliki kekurangan modal. Kurangnya modal tersebut dapat terjadi apabila bank tersebut memiliki jumlah modalnya kecil dan modal tersebut memiliki kualitas yang buruk. Dengan demikian faktor utama agar suatu bank tersebut dikatakan sehat yaitu harus memiliki jumlah dan kualitas modal yang cukup bagus dan hal tersebut menjadi tanggung jawab para pemegang saham.

2. Kualitas Aktifa Produktif

Dalam kondisi normal, sebagian besar aktif suatu bank terdiri dari kredit dan aktifa lain yang dapat menghasilkan atau menjadi sumber pendapatan bagai bank sehingga jenis aktifa tersebut sering disebut sebagai aktifa produktif dalam menganalisis kondisi suatu bank. Pada umumnya perhatian difokuskan pada kecukupan modal,demikian menganalisis kualitas aktifa produktf bank secara cermat tidak kalah pentingnya, karena kualitas aktifa produktif bank yang sangat buruk akan menghapus modal bank.

3. Manajemen

Pengevaluasian terhadap pengolahan bank tergantung pada penilaian dalam penelitian faktor manajemen yang bersangkutan.

4. Keuntungan (profit)

Ada 2 (dua) rasio penilaian terhadap faktor rentabilitas yaitu : rasio laba sebelum pajak dan rasio biaya operasional yang dihitung dalam periode yang sama selama setahun.

5. Likuiditas

Permasalahan yang sangat krusial dalam perbankan ialah Likuiditas, untuk itu pengawas bank harus memantau secara terus menerus masalah pengelolaan likuiditas yang baik. Perlu adanya transparasi laporan bank pada publik dan laporan-laporan tersebut juga harus berdasarkan penalaran-penalaran rasio-rasio yang terkait dengan kondisi likuiditas suatu bank, agar masyarakat mendapatkan segala informasi tentang adanya suatu bank yang mengalami risiko likuditas.

Adapun predikat tingkat kesehatan Bank yaitu:
a. $81-100$ predikat sehat
b. $66-<81$ predikat cukup sehat
c. $51-<66$ kurang sehat
d. $0-<51$ tidak sehat

Adapun tanggung jawab direksi dalam meningkatkan citra bank selain hal di atas yang mana direksi sebagai pihak terafiliasi adalah menyimpan rahasia bank. Menurut Muhamad Djumhana Rahasia Bank adalah segala sesuatu yang berkaitan dengan bank, baik itu mengenai keuangan maupun hal-hal yang berkaitan dengan pengguna jasa bank wajib untuk dirahasiakan. ${ }^{7}$

Adapun penafsiran yang diberikan oleh Bank Indonesia terhadap rahasia bank tersebut dicantumkan dalam Surat Edaran BI 2 / 337 UPPB/PbB tanggal 11 September 1969, adalah sebagai berikut:

1. Keadaan keuangan nasabah yang tercatat padanya, ialah keadaan mengenai keuangan yang tercatat pada bank yang meliputi segala simpanannya yang tercantum dalam semua pos pasiva, dan segala pos aktiva yang merupakan pemberian kredit dalam berbagai macam bentuk kepada yang bersangkutan.

2. Kerahasian Bank yang lain yang menyangkut segala sesuatu keterangan nasabah, meliputi:

a. Pemberian pelayanan, dan jasa dalam lalu lintas uang, baik dalam maupun luar negeri.

b. Pendiskontoan, dan jual beli surat berharga

c. Pemberian kredit

Agar dapat menumbuhkan serta meningkatkan kepercayaan agar Masyarakat tersebut dapat menyimpan uang atau menggunakan jasa bank maka bank tersebut harus menjaga kerahasian informasi yang timbul dalam kegiatan perbankan yang dapat menjadikan suatu jaminan bagi nasabah.

Ada 2 (dua) pendapat mengenai teori Kerahasian Bank yaitu :

1. Teori rahasia bank bersifat mutlak, artinya segala bentuk keterangan atau rahasia nasabah yang menggunakan jasa bank, maka bank tersebut berkewajiban untuk menyimpan identitas atau keterangan nasabah tersebut dalam keadaan apapun dan tidak dapat diganggu gugat oleh siapapun.

2. Teori rahasia bank bersifat relatif, yaitu jika Negara menginginkan suatu keterangan atau kerahasiaan tersebut maka bank diwajibkan untuk membuka rahasia nasabanhya. Teori relatif ini memiliki pertimbangan yang khusus

${ }^{7}$ Ibid., Halaman 11 
artinya melihat bagaimana keadaan, mana yang harus dan mana yang tidak harus untuk dapat dibukanya suatu kerahasiaan bank.

\section{Kendala-Kendala Yang Di Hadapi Direksi Dalam Meningkatkan Citra Bank}

1. Meningkatnya angka kredit bermasalah

Kredit- kredit yang banyak disalurkan oleh bank selama ini tidak selamanya mulus, akan tetapi ada juga yang mengalami permasalahan dan itu disebabkan oleh ketidakmampuan debitur untuk membayar kewajibannya sehingga berakibat angka kredit dapat menjadi kredit bermasalah. Ada beberapa Faktor yang menyebabkan kredit tersebut mengalami permasalahan yaitu :

a. Faktor Intern, kredit bermasalah yang timbul sebagai akibat dari adanya itikad buruk, dari pejabat bank atau pun pemilik atau pengurus bank dan juga kondisi perekonomian yang mengakibatkan iklim persaingan perbankan yang kurang / tidak sehat.

b. Faktor Ekstern, kredit bermasalah yang timbul sebagai akibat dari debitur, diantaranya debitur yang bersengketa pada waktu mengajukan permohonan kreditnya, debitur yang telah berniat untuk tidak akan melaksanakan kewajibannya dalam pembayaran anggsuran kreditnya.

Jadi, meningkatnya angka kredit bermasalah merupakan kendala yang dihadapi, dengan adanya hal tersebut citra bank yang selama ini dibangun menjadi tidak baik.

2. Manajemen Risiko Oprasional Yang Belum Optimal

Pada saat ini telah terbangun suatu mitos di masyarakat bahwa, merupakan suatu aib bagi sebuah bank jika di bank tersebut terjadi skandal yang melibatkan orang dalam. Artinya bank seharusnya merupakan institusi yang bebas dari risiko oprasional. Risiko oprasional merupakan resiko yang terjadi melalui proses internal dari manusia serta dari sistem yang mengalami kegagalan yang mendapat menimbulkan suatu kerugian sehingga berdampak pada keseluruhan sistem yang ada pada bank tersebut. Dampak yang akan mungkin ditimbulkan dari kegagalan sistem tersebut diantaranya :

a. Bank akan mengalami kebangkrutan akibat dari investasi yang berkurang

b. Reputasi Bank yang buruk yang dapat menurunkan harga saham

c. Kerugian yang akan ditranggung oleh para pemegang saham akibat dari hilangnya deviden penurunan laba perusahaan.

\section{Upaya Mengatasi Kendala Dalam Meningkatkan Citra Bank}

Dalam Era Globalisasi dapat dipastikan bahwa, masalah tanggung jawab direksi dalam meningkatkan citra bank harus dilakukan secara efisien dan seefektif mungkin. Adapun upaya mengatasi kendala yang dihadapi, yaitu sebagai berikut :

1. Penyelesaian kredit yang memiliki masalah

Kebijakan-kebijakan yang diambil dalam rangka menyelesaikan kredit-kredit yang memiliki masalah yaitu:

a. Melalui Rescheduling ( Penjadwalan Kembali ), yaitu suatu upaya hukum untuk melakukan perubahan terhadap beberapa syarat perjanjian kredit yang berkenaan dengan jadwal pembayaran kembali / jangka waktu kredit termaksud tenggang waktu maupun jumah angsuran, bila perlu dengan penambahan kredit.

b. Melalui Reconditioning ( Persyaratan Kembali), yaitu melakukan perubahan atas sebagian atau seluruh persyaratan perjanjian, yang tidak terbatas hanya kepada perubahan jadwal angsuran, dan atau jangka waktu kredit saja, tetapi perubahan kredit tersebut tanpa memberikan tambahan kredit atau tanpa melakukan konversi atas seluruh atau sebagian dari kredit menjadi eguity perusahaan

c. Restructuring ( Penataan kembali), yaitu upaya berupa melakukan perubahan syarat-syarat perjanjian kredit berupa pemberian tambahan kredit.

Bank Indonesia dalam membantu mengantisipasi kredit bermasalah perbankan, telah mengambil langkah yang arahnya diharapkan dapat mencegah terjadinya kredit bermasalah, yaitu:

a. Setiap bank harus mempunyai pedoman kebijaksanaan dalam pengkreditan yang harus disusun secara rinci agar setiap proses pemberian kredit tersebut dapat mempergunakannya.

b. Bank harus memiliki sistem informasi kredit dan daftar kredit yang akurat sehingga dalam sistem informasi kredit bermasalah mudah diketahui.

c. Pengurus Bank haruslah mempunyai kualikasi terbebas dari datar orang yang memiliki masalah dalam kredit (debitu macet).

d. Pelaksanaan fungsi internal audit pada bank, agar bank melaksanakan fungsi internal auditnya.

e. Policy statement pemberian kredit kepada group memilki /pengurus bank dan debitur tertentu. ${ }^{8}$

2. Upaya Mengatasi Manajemen Risiko Oprasional Yang Belum Optimal

${ }^{8}$ Sentosa, Sembiring, Hukum Perbankan, CV. Mandar Maju,Bandung, 2000, Halaman 126 
Pengelolaan risiko yang harus dilakukan oleh bank sehingga bank dalam melakukan kegiatan bisnisnya dan struktur pengawasan meliputi :

a. Identifikasi Risiko

Unit manajemen risiko bertugas untuk mengidentifikasi faktor- faktor risiko yang terjadi.

b. Pengukuran Risiko

Analisis risiko harus memiliki pencatatan produk dan bisnis yang dibuat dalam periode tertentu yang berdasarkan sumber data yang digunakan sehingga memiliki kemampuan dalam perubahan-perubahan pada profil risiko

c. Pemantauan Risiko

Proses monitoring risiko harus mengevaluasi sebelum ekspor risiko dan membuat proses pelaporan yang merefleksikan setiap perubahan profil risiko bank. Proses ini harus membuat struktur yang dapat mengelola setiap risiko yang diperkirakan akan menjadi ancaman potensial terhadap kelangsungan bisnis bank.

d. Pengendalian Risiko

Dewan direksi harus memastikan bahwa bank mengimplementasikan sistem kontrol internal derdasarkan aktivitas bisnis terhadap opersi bank secara keseluruhan.Sistem kontrol internal harus mengidentifikasikan setiap kegagalan pengontrolan (pengendalian) serta di evaluasi dari kebijakan prosedur dan proses yang dimiliki bank

Dimana diperlukan sistem kontrol internal yaitu :

a. Memenuhi Peraturan Bank Indonesia

b. Memenuhi aturan internal bank yang ditetapkan oleh dewan direksi

c. Menggunakan informasi finansial dalam proses pelaporan yan komprehensif, akurat, dan up-to-date

d. Mampu mendukung manajemen dalam membut keputusan untuk menerima atau menurunkan risiko

e. Mambangun budaya pelaporan berbasis risiko di seluruh bank

Oleh sebab itu diperlukan peran internal audit dan peran eksternal audit. Internal audit merupakan sebuah fungsi yang independen di bank, tugas utamanya adalah melakukan penelitian berkelanjutan melalui penyusunan laporan yang menganalisis metodologi, prosedur dan proses di dalam organisasi manajemen risiko bank. Sedangkan eksternal audit merupakan sebuah fungsi yang non idenpeden di bank yang mana pengaruhnya datang dari luar bank tersebut. Selain hal diatas sangat diperlukan kualitas dan kuantitas manusia yang handal yang mampu mengelola risiko oprasional dengan baik, serta dapat menerapkan prinsip- prinsip perbankan dalam melakukan menejemen oprasional dalam setiap kegiatannya. Dengan begitu maka citra bank dapat tatap terjaga dengan baik.

\section{SIMPULAN}

Adapun kesimpulan yang dapat diambil dari hasil pembahasan permasalahan diatas yaitu :

1. Adapaun tanggung jawab direksi mempunyai tanggung jawab penuh atas kepengurusan bank, direksi juga wajib mengelola bank sesuai kewewenagan dan tanggung jawabnya sebagaimana diatur dalama anggaran dasardan peraturan perundang-undanganyang berlaku. Citra bank di bangun melalui program komunikasi dan dipadukan oleh pengalaman nasabah berinteraksi dengan bank.Citra bank dapat juga ditunjukan dengan bank yang besar, produknya, pelayanannya, serta banyaknya nasabah.

2. Kendala direksi dalam meningkatkan citra bank yaitu meningkatnya angka kredit bermasalah, Manajemen risiko oprasional yang belum optimal, yang berdampak baik itu bagi Pemegang Saham, pegawai bank ,maupun bagi nasabahnya.

3. Adapun upaya yang dilakukan adalah sebagai berikut; Penyelesaian kredit bermasalah dapat dilakukan dengan cara negosiasi dan dengan cara litigasi, serta untuk mengatasi risiko oprasional maka dapat dilakukan dalam 4 (empat tahap) yaitu: risiko diidentifikasi terlebih dahulu, pengukuran risiko, pemantauan risiko, dan pengendalian risiko.

\section{PUSTAKA}

Guza, Afnil, Himpunan Undang-Undang Perbankan No. 10 Tahun 1998.

, Undang- Undang Bank Indonesia No.3 Tahun 2004.

Hardanto Sri Sulad, Manajemen Risiko Bagi Bank Umum, PT. Elek Media Komputindo, Jakarta, 2006.

Djumhana, Muhamad, Hukum Perbankan Di Indonesia, PT.Citra Aditya Bakti, Bandung, 2000.

Hermansyah, Hukum Perbankan Nasional Indonesia, Cetakan 1, Prenada Media, Jakarta, 2005.

Sentosa, Sembiring, Hukum Perbankan, CV. Mandar Maju,Bandung, 2000.

Widjanarto, Hukum dan Ketentuan Perbankan di Indonesia, Grafiti,Jakarta, 2005 


\section{Internet}

http: // www. Infobanknews. Com/ artikel/ rubrik/ artikel/- cetak. Php ? aid= ...

http: // www. bank jambi.co.id /?v=vscf \&id=15

http://www.peraturan.bank.indonesia.co.id 